\title{
Faktor-faktor yang Berhubungan Dengan Unmet Need KB Pasca-Salin IUD post-placenta di Kamar Rawat Pasca-bersalin RSUP DR. M. Djamil periode Januari-Maret 2013
}

\author{
Sari Handayani Utami ${ }^{1}$, Desmiwati ${ }^{2}$, Endrinaldi ${ }^{3}$
}

\begin{abstract}
Abstrak
Wanita pada periode post-partum memiliki angka unmet need terhadap kontrasepsi, padahal ini waktu yang tepat untuk mulai memakai kontrasepsi. Salah satu kontrasepsi pasca-salin terkini yang mulai disosialisasikan adalah IUD post-placenta. Namun demikian, masih belum banyak wanita pasangan usia subur yang menggunakan alat kontrasepsi ini bahkan mengetahuinya. Tujuan dari penelitian ini adalah untuk mengetahui faktor-faktor yang berhubungan dengan unmet need KB pasca-salin IUD post-placenta. Jenis penelitian survey dengan desain cross sectional study. Waktu pengambilan data dari 12 Januari sampai dengan 12 Maret 2013. Sampel adalah wanita pasangan usia subur yang melahirkan pervaginam dan dipilih secara accidental sampling. Penelitian dilakukan pada 88 orang responden dengan 50 orang bukan akseptor KB IUD post-placenta dan 38 orang akseptor KB IUD Postplacenta. Pengumpulan data dilakukan menggunakan kuesioner melalui wawancara terpimpin. Data dianalisis secara univariat dan bivariat. Hasil penelitian menunjukkan faktor yang memiliki hubungan signifikan dengan unmet need IUD post-placenta adalah faktor pengetahuan ( $p$ value $=0,001$ ), sedangkan faktor lain yang tidak memiliki hubungan signifikan adalah faktor pendidikan ( $p$ value $=0,222$ ), faktor status ekonomi ( $p$ value $=1,000$ ), dan faktor konseling KB (p value $=0,583$ )
\end{abstract}

Kata kunci: faktor yang berhubungan, unmet need, KB pasca-salin, IUD post-placenta

\begin{abstract}
The women in post-partum period have unmet need rate to contraception, whereas it's approriate time to start using contraception. One of recent post-partum contraception method is IUD post-placenta. But, only a few women of fertile age couple use this contraception even has known it. The purpose of this study was to determine the factors associated to unmet need of post-partum contraception IUD post-placenta. This survey study with cross sectional design study. The data was collected from January 12 until March 12 2013. The subject were women of fertile age couple who give birth per vaginam and selected by accidental sampling. This study had 88 respondents consists of 50 as not IUD Post-placenta acceptors and 38 respondents as IUD post-placenta acceptors. The data collected by using questionnaire through guided interview and analyzed through univariate and bivariate. The result of analysis showed that the factor had significant relation to unmet need of IUD post-placenta is knowledge ( $p$ value $=0,001)$, while another factors did not have significant relation are education level ( $p$ value $=0,222)$, economic level $(p$ value $=1,000)$, and family planning counselling ( $p$ value $=0,583$ ).
\end{abstract}

Keywords:the relating factors, unmet need, post-partum contraception, IUDpost-placenta

Affiliasi penulis : ${ }^{1}$ Mahasiswa FK Unand, ${ }^{2}$ Bagian Obgyn FK Unand, ${ }^{3}$ Bagian Kimia FK Unand

Korespondensi :Fakultas Kedokteran Universitas Andalas JI. Perintis Kemerdekaan No.94, Padang. Email : ${ }^{1}$ sari utami18@yahoo.co.id, Telp: 085266357882

\section{PENDAHULUAN}

Masalah kesakitan dan kematian lbu di Indonesia masih merupakan masalah besar di negara ini. Berdasarkan Survei Demografi dan Kesehatan Indonesia (SDKI) 2007, angka kematian lbu di Indonesia menunjukkan 248 per 100.000 kelahiran hidup. Angka ini masih perlu diturunkan lagi jika melihat angka target Millenium Development Goals (MDG's) tahun 2015, yaitu 102 per 100.000 kelahiran hidup. $^{1,2}$

Salah satu program untuk menurunkan Angka Kematian Ibu adalah program Keluarga Berencana. Program Keluarga Berencana berperan dalam menurunkan angka kematian Ibu melalui upaya pencegahan kehamilan, penundaan usia kehamilan, dan menjarangkan kehamilan. ${ }^{3}$ Pemberian konseling Keluarga Berencana dan metode kontrasepsi selama masa pasca persalinan dapat meningkatkan kesadaran lbu untuk menggunakan kontrasepsi. ${ }^{4} \mathrm{Hal}$ ini dikarenakan pada sebagian wanita setelah melahirkan biasanya tidak menginginkan kehamilan atau menunda kehamilan sampai 2 tahun setelah melahirkan tetapi mereka tidak menggunakan kontrasepsi (unmet need). ${ }^{5}$

Unmet need adalah tidak terpenuhinya pemakaian kontrasepsi pada wanita yang ingin mengakhiri atau menunda kehamilan sampai 24 bulan. ${ }^{1}$ Studi yang dilakukan oleh Ross dan Frakenberg (1993) menunjukkan wanita pada masa pasca persalinan mempunyai unmet need untuk kontrasepsi, wanita pada masa ini menunjukkan keinginan untuk tidak hamil selama 2 tahun setelah melahirkan tetapi mereka tidak menggunakan kontrasepsi. $^{5}$ Walaupun data tidak tersedia pada semua negara, tetapi selama tahun 2000-2007, unmet need untuk kontrasepsi berkisar $13 \%$ untuk regio Asia Tenggara dan $24 \%$ untuk Afrika. ${ }^{6}$ Sedangkan untuk Indonesia, berdasarkan SDKI 2007, angka unmet need Indonesia meningkat dari 8,6\% (SDKI 2002/2003) menjadi 9,1\%. Berdasarkan Riskesdas 2007, provinsi Sumatera Barat merupakan salah satu provinsi di Indonesia yang mempunyai angka unmet need yang tinggi yakni mencapai $11,2 \%$ dan pada tahun 2010 unmet need di provinsi Sumatera Barat berada diatas standar nasional yaitu mencapai $12,4 \%{ }^{7}$ 
Studi mengenai penggunaan kontrasepsi pasca persalinan pada wanita di Indonesia masih terbatas. $^{5}$ Namun demikian, berdasarkan hasil pemantauan BKKBN terhadap pelayanan Keluarga Berencana pasca persalinan dan pasca-keguguran di 22 Rumah Sakit (14 provinsi) pada tahun 2008-2009, wanita yang ber-KB setelah bersalin dan keguguran rata-rata hanya $5-10 \%{ }^{8}$

Adapun salah satu alat kontrasepsi yang termasuk dalam KB pasca-partum adalah alat kontrasepsi yang dapat langsung dipasang pada saat 10 menit setelah plasenta dilahirkan, yaitu IUD (Intra Uterine Device). Pemasangan alat kontrasepsi ini setelah plasenta dilahirkan dirasakan menguntungkan untuk beberapa alasan tertentu, seperti pada masa ini wanita tersebut tidak ingin hamil dan motivasinya untuk memasang alat kontrasepsi masih tinggi. ${ }^{9}$ IUD ini dapat digunakan bertahun-tahun dan ini akan menghemat biaya apalagi jika pemasangan dapat langsung dilakukan di fasilitas kesehatan tempat lbu melahirkan. $^{4}$

Pemasangan IUDpost-placenta dan segera pasca persalinan direkomendasikan karena pada masa ini serviks masih terbuka dan lunak sehingga memudahkan pemasangan IUD dan kurang nyeri bila dibandingkan pemasangan setelah 48 jam pasca persalinan. Insersi IUDpost-placenta memiliki angka ekspulsi rata-rata $13-16 \%$, dan dapat hingga 9-12,5\% jika dipasang oleh tenaga terlatih. Angka ekspulsi ini lebih rendah bila dibandingkan dengan waktu pemasangan pada masa segera pasca-persalinan (immediate postpartum), yaitu $28-37 \% .{ }^{4}$ Sayangnya, pemasangan IUDpost-placenta belum terlalu banyak digunakan karena masih kurangnya sosialisasi mengenai hal ini dan masih adanya ketakutan pada calon akseptor mengenai terjadinya komplikasi seperti perforasi uterus, infeksi, perdarahan, dan nyeri. ${ }^{10}$ Padahal pemasangan pada masa ini aman, memiliki risiko kecil untuk infeksi, sedikit perdarahan, dan angka perforasi yang rendah. Angka kehamilan yang tidak direncanakan (unplanned pregnancy) pada pemasangan alat kontrasepsi pada masa ini adalah 22,8 per 100 pemakai selama 24 bulan pemasangan IUD Copper modern. ${ }^{11}$

RSUP dr. M.Djamil yang merupakan Rumah Sakit Umum Pusat di kota Padang telah memberikan pelayanan pemasangan alat kontrasepsi pasca-salin. Data yang didapatkan dari RSUP M.Djamil menunjukkan bahwasanya pada tahun 2011 dari 1419 ibu yang bersalin di kamar bersalin hanya $120 \mathrm{lbu}$ yang menggunakan kontrasepsi pasca-salin IUD postplacenta dengan presentase $8,45 \%$.

Penelitian ini bertujuan untuk mengetahui faktor-faktor Yang Berhubungan Dengan Unmet Need KB Pasca-salin IUDPost-placenta di Kamar Rawat Pasca-bersalin RSUP Dr. M.Djamil periode JanuariMaret 2013.

\section{METODE}

Penelitian ini menggunakan metode survey analitik dengan pendekatan cross sectional. Penelitian ini dilakukan di Kamar Rawat Pasca-bersalin RSUP dr. M.Djamil, Kota Padang dari 12 Januari 2013 sampai dengan 12 Maret 2013. Subjek dalam penelitian ini adalah wanita Pasangan Usia Subur pasca-persalinan pervaginam. Kriteria inklusinya adalah wanita Pasangan Usia Subur pascapersalinan pervaginam di lokasi penelitian dan dalam keadaan sehat serta bersedia menjadi responden.
Sedangkan kriteria eksklusinya adalah wanita pasangan usia subur dengan kontraindikasi pemasangan IUD pasca persalinan post-placenta seperti adanya gejala PID (Pelvic Inflammatory Disease), perdarahan antepartum, perdarahan pervaginam yang belum diketahui sebabnya, dll dan wanita Pasangan Usia Subur yang sudah pasti akan menjalani MOW (Metode Operasi Wanita).

Metode pemilihan subject adalah accidental sampling. Instrumen penelitian yang digunakan adalah kuesioner yang ditanyakan melalui wawancara terpimpin. Langkah-langkah pengolahan data adalah dengan melakukan pemeriksaan kelengkapan (checking), pemberian kode pada setiap data (coding), memasukkan data (entry) dalam program SPSS (Statistical Program for Social Science) dan pemeriksaan kembali terhadap kemungkinan kesalahan (cleaning). Data yang diperoleh diolah dengan menggunakan program SPSS versi 16.0 dan dianalisis secara univariat dan bivariat.

\section{HASIL DAN PEMBAHASAN}

\section{a. Karakteristik responden}

Tabel 1. Karakteristik responden berdasarkan umur, pekerjaan dan jumlah anak

\begin{tabular}{|c|c|c|c|c|c|}
\hline \multirow{2}{*}{\multicolumn{2}{|c|}{ Karakteristik }} & \multicolumn{2}{|c|}{$\begin{array}{l}\text { Met Need IUD } \\
\text { Post-placenta }\end{array}$} & \multicolumn{2}{|c|}{$\begin{array}{c}\text { Unmet } \\
\text { NeedIUD } \\
\text { post- } \\
\text { placenta }\end{array}$} \\
\hline & & $f$ & $\%$ & $f$ & $\%$ \\
\hline \multicolumn{6}{|l|}{ Umur } \\
\hline - & $<20$ tahun & 1 & 2,6 & 2 & 4 \\
\hline - & 20-35 tahun & 30 & 79 & 39 & 78 \\
\hline- & $>35$ tahun & 7 & 18,4 & 9 & 18 \\
\hline Jumlah & & 38 & 100 & 50 & 100 \\
\hline \multicolumn{6}{|l|}{ Pekerjaan } \\
\hline 8 & $\begin{array}{l}\text { lbu Rumah } \\
\text { Tangga }\end{array}$ & 27 & 71 & 42 & 84 \\
\hline \multirow[t]{2}{*}{-} & Pegawai & 0 & 0 & 1 & 2 \\
\hline & Negeri & 3 & 7,9 & 1 & 2 \\
\hline \multirow[t]{2}{*}{-} & Pegawai & 4 & 11 & 1 & 2 \\
\hline & Swasta & 1 & 2,6 & 3 & 6 \\
\hline- & Pedagang & 3 & 7,9 & 2 & 4 \\
\hline- & Petani & & & & \\
\hline- & Lain-lain & & & & \\
\hline \multicolumn{2}{|l|}{ Jumlah } & 38 & 100 & 50 & 100 \\
\hline \multicolumn{6}{|c|}{ Jumlah anak hidup } \\
\hline$-\quad$ & $\leq 2$ anak & 24 & 63,2 & 18 & 36 \\
\hline- & >2 anak & 14 & 36,8 & 32 & 64 \\
\hline \multicolumn{2}{|l|}{ Jumlah } & 38 & 100 & 50 & 100 \\
\hline \multicolumn{6}{|c|}{$\begin{array}{ll}\text { Riwayat } & \text { pasang } \\
\text { kontrasepsi } & \end{array}$} \\
\hline- & Sudah & 20 & 52,6 & 22 & 44 \\
\hline- & Belum & 18 & 47,4 & 28 & 56 \\
\hline Jumlah & & 38 & 100 & 50 & 100 \\
\hline
\end{tabular}

Berdasarkan tabel 1. dapat dilihat pada kelompok wanita Pasangan Usia Subur yang unmet need IUD post-placenta, paling banyak adalah responden yang berumur diantara 20-35 tahun (78\%). Sedangkan berdasarkan pekerjaan,mayoritas lbu Rumah Tangga, yakni sebesar $84 \%$.Jika dilihat dari jumlah anak hidup yang dimiliki oleh responden, 64\% responden memiliki anak lebih dari dua orang. Berdasarkan riwayat pemasangan kontrasepsi, sebanyak 28 responden (56\%) belum pernah menggunakan alat kontrasepsi apapun sebelumnya.

\section{Analisis Univariat}

\section{b. Dukungan keluarga}


Tabel 2. Distribusi frekuensi responden berdasarkan dukungan keluarga

\begin{tabular}{|c|c|c|c|c|}
\hline \multirow[t]{2}{*}{ Karakteristik } & \multicolumn{2}{|c|}{$\begin{array}{c}\text { Met } \\
\text { needIUD } \\
\text { Post- } \\
\text { placenta }\end{array}$} & \multicolumn{2}{|c|}{$\begin{array}{c}\text { Unmet } \\
\text { need IUD } \\
\text { post- } \\
\text { placenta }\end{array}$} \\
\hline & f & $\%$ & $f$ & $\%$ \\
\hline Mendukung & 38 & 100 & 41 & 82 \\
\hline $\begin{array}{ll}\text { - } \quad \text { Tidak } & \text { mendukung }\end{array}$ & 0 & 0 & 9 & 18 \\
\hline
\end{tabular}

\begin{tabular}{lllll}
\hline Jumlah & 38 & 100 & 50 & 100 \\
\hline
\end{tabular}

Berdasarkan tabel 2., dukungan keluarga pada kelompok responden yang unmet need IUD postplacenta adalah $82 \%$ dan $18 \%$ sisanya menyatakan ada suami atau anggota keluarganya yang melarangnya untuk memakai IUD setelah melahirkan.

\section{c. Pengetahuan}

Tabel 3. Distribusi frekuensi responden berdasarkan pengetahuan

\begin{tabular}{cccccc}
\hline \multirow{2}{*}{ Karakteristik } & \multicolumn{2}{c}{$\begin{array}{c}\text { Met needIUD } \\
\text { Post- } \\
\text { placenta }\end{array}$} & \multicolumn{2}{c}{$\begin{array}{c}\text { Unmet need } \\
\text { IUD post- } \\
\text { placenta }\end{array}$} \\
\cline { 2 - 6 } & f & $\%$ & f & $\%$ \\
\hline- & Baik & 33 & 86,8 & 26 & 52 \\
- & Kurang & 5 & 13,2 & 24 & 48 \\
\hline Jumlah & & $\mathbf{3 8}$ & $\mathbf{1 0 0}$ & $\mathbf{5 0}$ & $\mathbf{1 0 0}$ \\
\hline
\end{tabular}

Berdasarkan tabel 3., pada responden yang unmet need IUD post-placenta, sebanyak 52\% memiliki pengetahuan yang baik mengenai kontrasepsi, sedangkan $48 \%$ memiliki pengetahuan yang kurang mengenai kontrasepsi.

\section{d. Pendidikan}

Tabel 4. Distribusi frekuensi responden berdasarkan pendidikan

\begin{tabular}{|c|c|c|c|c|}
\hline \multirow[t]{2}{*}{ Karakteristik } & \multicolumn{2}{|c|}{$\begin{array}{c}\text { Met } \\
\text { needIUD } \\
\text { Post- } \\
\text { placenta }\end{array}$} & \multicolumn{2}{|c|}{$\begin{array}{l}\text { Unmet need } \\
\text { IUD post- } \\
\text { placenta }\end{array}$} \\
\hline & $f$ & $\%$ & $f$ & $\%$ \\
\hline Tingg & 27 & 71 & 28 & 56 \\
\hline Rendah & 11 & 29 & 22 & 44 \\
\hline Jumlah & 38 & 100 & 50 & 100 \\
\hline
\end{tabular}

Berdasarkan tabel 4. pada kelompok responden yangunmet need IUD post-placenta, responden yang berstatus pendidikan tinggi adalah sebesar $56 \%$ dan $44 \%$ berstatus pendidikan rendah.

\section{e. Status ekonomi}

Tabel 5. Distribusi frekuensi responden berdasarkan status ekonomi

\begin{tabular}{cccccc}
\hline Karakteristik & \multicolumn{2}{c}{$\begin{array}{c}\text { Met } \\
\text { needIUD } \\
\text { Post- } \\
\text { placenta }\end{array}$} & $\begin{array}{c}\text { Unmet need } \\
\text { IUD post- } \\
\text { placenta }\end{array}$ \\
\cline { 2 - 6 } & $\mathbf{f}$ & $\%$ & $\mathbf{f}$ & $\%$ \\
\hline- & Mampu & 10 & 26,3 & 14 & 28 \\
& Kurang & 28 & 73,7 & 36 & 72 \\
\hline Jumlah & mampu & & & & \\
\hline
\end{tabular}

Berdasarkan tabel 5. pada kelompok responden yangunmet need IUD Post-placenta, responden yang berstatus ekonomi kurang mampu adalah sebesar $72 \%$, sedangkan responden yang berstatus mampu adalah $28 \%$.

\section{f. Konseling KB}

Tabel 6. Distribusi frekuensi responden berdasarkan konseling KB

\begin{tabular}{|c|c|c|c|c|c|}
\hline \multirow{2}{*}{\multicolumn{2}{|c|}{ Karakteristik }} & \multicolumn{2}{|c|}{$\begin{array}{c}\text { Met needIUD } \\
\text { Post- } \\
\text { placenta }\end{array}$} & \multicolumn{2}{|c|}{$\begin{array}{c}\text { Unmet need } \\
\text { IUD post- } \\
\text { placenta }\end{array}$} \\
\hline & & $f$ & $\%$ & $f$ & $\%$ \\
\hline- & Baik & 12 & 31,6 & 12 & 24 \\
\hline - & $\begin{array}{l}\text { Kuran } \\
\mathrm{g}\end{array}$ & 26 & 68,4 & 38 & 76 \\
\hline \multicolumn{2}{|c|}{ Jumlah } & 38 & 100 & 50 & 100 \\
\hline
\end{tabular}

Berdasarkan tabel 6 . dapat dilihat pada kelompok responden yang unmet need IUD postplacenta, sebesar $76 \%$ responden mendapatkan konseling KB yang kurang sedangkan 24\% mendapatkan konseling KB yang baik.

Analisis Bivariat

Tabel 7. Hubungan dukungan keluarga dengan unmet need KB pasca-salin IUD post-placenta

\begin{tabular}{|c|c|c|c|c|c|c|c|}
\hline \multirow{3}{*}{$\begin{array}{c}\text { Dukungan } \\
\text { Keluarga }\end{array}$} & \multicolumn{4}{|c|}{ Wanita PUS } & & & \multirow{3}{*}{$\begin{array}{c}p \\
\text { valu } \\
e\end{array}$} \\
\hline & \multicolumn{2}{|c|}{$\begin{array}{c}\text { Unmet } \\
\text { need IUD } \\
\text { Post- } \\
\text { placenta }\end{array}$} & \multicolumn{2}{|c|}{$\begin{array}{c}\text { Met } \\
\text { needIUD } \\
\text { post- } \\
\text { placenta }\end{array}$} & \multicolumn{2}{|c|}{ Total } & \\
\hline & $f$ & $\%$ & $f$ & $\%$ & $f$ & $\%$ & \\
\hline $\begin{array}{l}\text { Tidak } \\
\text { mendukung }\end{array}$ & 9 & 100 & 0 & 0 & 9 & 100 & - \\
\hline Mendukung & 41 & 51,9 & 38 & 48,1 & 79 & 100 & \\
\hline Total & 50 & & 38 & & 88 & & \\
\hline
\end{tabular}

Berdasarkan tabel 7. dapat dilihat dari 79 responden yang mendapat dukungan dari keluarga, yang unmet need IUD (51,9\%) dan responden yang met needIUD (48,1\%). Hasil uji statistik dengan menggunakan Chi-square tidak dapat menyatakan ada tidaknya hubungan antara dukungan keluarga dengan unmet need KB pasca-salin IUD post-placenta disebabkan pada kolom kelompok responden yang met needIUD post-placenta, didapatkan tidak adanya keluarga responden yang tidak mendukung. ${ }^{12}$

Namun demikian, dari tabel dapat dilihat adanya kecenderungan dari responden yang tidak mendapatkan dukungan dari keluarganya untuk tidak menggunakan IUD post-placenta (unmet need), sementara semua responden yang langsung memakai IUD post-placenta (met need) mendapatkan dukungan dari keluarganya. 
Program KB dapat terwujud dengan baik bila ada dukungan dari pihak-pihak tertentu. Menurut Hartanto (1996), metode kontrasepsi tidak dapat dipakai oleh istri tanpa adanya kerjasama dari suaminya dan saling percaya. Selain suami, anggota keluarga lain baik dari keluarga istri maupun suami juga memiliki pengaruh yang bermakna dalam pemakaian metode kontrasepsi oleh suatu pasangan. ${ }^{13}$ Pada masyarakat Minangkabau yang mengenal keluarga komunal (extended family), tentu saja juga akan mempengaruhi cara pengambilan keputusan oleh pasangan usia subur untuk memilih jenis alat kontrasepsi yang akan digunakan oleh istrinya. Hasil analisis lanjut SDKI 2007 yang dilakukan oleh Puslitbang BKKBN mendapatkan adanya asosiasi positif antara persetujuan suami dengan penggunaan kontrasepsi pada istrinya. ${ }^{14}$

Tabel 8. Hubungan pengetahuan dengan unmet need KB pasca-salin IUD Post-placenta

\begin{tabular}{|c|c|c|c|c|c|c|c|}
\hline \multirow{3}{*}{ Pengetahuan } & \multicolumn{4}{|c|}{ Wanita PUS } & & & \multirow{3}{*}{$\begin{array}{c}p \\
\text { value }\end{array}$} \\
\hline & \multicolumn{2}{|c|}{$\begin{array}{c}\text { Unmet } \\
\text { need IUD } \\
\text { Post- } \\
\text { placenta }\end{array}$} & \multicolumn{2}{|c|}{$\begin{array}{c}\text { Met } \\
\text { needIUD } \\
\text { post- } \\
\text { placenta }\end{array}$} & \multicolumn{2}{|c|}{ Total } & \\
\hline & $f$ & $\%$ & $f$ & $\%$ & $f$ & $\%$ & \\
\hline Kurang & 24 & 82,8 & 5 & 17,2 & 29 & 100 & \\
\hline Baik & 26 & 44,1 & 33 & 55,9 & 59 & 100 & 0,001 \\
\hline Total & 50 & & 38 & & 88 & & \\
\hline
\end{tabular}

Berdasarkan tabel 8. dapat dilihat bahwa responden dengan pengetahuan baik yang met need IUD post-placenta sebanyak $55,9 \%$ dan yang unmet need IUD post-placenta adalah sebesar $44,1 \%$, sedangkan responden dengan pengetahuan kurang yang unmet need IUD Post-placenta adalah sebanyak $82,8 \%$ dan yang met need IUD adalah sebanyak $17,2 \%$. Hasil uji statistik dengan menggunakan Chisquare, diperoleh nilai $p=0,001 \quad(p<0,05)$. Berdasarkan hasil tersebut, dapat disimpulkan bahwa ada hubungan yang bermakna antara pengetahuan dengan unmet need KB Pasca-salin IUD PostPlacenta.

Menurut Notoatmodjo (2007), pengetahuan merupakan hasil dari tahu dan ini terjadi setelah seseorang melakukan penginderaan terhadap objek tertentu. Penginderaan terjadi melalui panca indera manusia, yaitu indera penglihatan, pendengaran, penciuman, rasa dan raba. ${ }^{15}$ Tingkat pengetahuan yang diteliti dalam penelitian ini adalah pengetahuan wanita PUS mengenai manfaat pemakaian kontrasepsi secara umum setelah melahirkan, jenis alat kontrasepsi yang telah diketahui oleh responden, dan mengenai alat kontrasepsi IUD post-placenta. Pada umumnya, responden yang unmet need IUD post-placenta belum mengenal IUDapalagi IUD yang dapat dipasang langsung dalam 10 menit setelah melahirkan. Penelitian ini sejalan penelitian Destyowati yang menyatakan adanya hubungan tingkat pengetahuan lbu tentang IUD dengan minat pemakaian kontrasepsi IUD $(p=0,000) .{ }^{16}$
Tabel 9. Hubungan pendidikan dengan unmet need KB pasca-salin IUD Post-placenta

\begin{tabular}{|c|c|c|c|c|c|c|c|}
\hline \multirow{3}{*}{ Pendidikan } & \multicolumn{4}{|c|}{ Wanita PUS } & & & \multirow{3}{*}{$\begin{array}{c}p \\
\text { value }\end{array}$} \\
\hline & \multicolumn{2}{|c|}{$\begin{array}{c}\text { Unmet } \\
\text { need IUD } \\
\text { Post- } \\
\text { placenta }\end{array}$} & \multicolumn{2}{|c|}{$\begin{array}{c}\text { Met } \\
\text { needlUD } \\
\text { post- } \\
\text { placenta }\end{array}$} & \multicolumn{2}{|c|}{ Total } & \\
\hline & f & $\%$ & $f$ & $\%$ & $f$ & $\%$ & \\
\hline Rendah & 22 & 66,7 & 11 & 33,3 & 33 & 100 & \\
\hline Tinggi & 28 & 51 & 27 & 49 & 55 & 100 & 0,222 \\
\hline Total & 50 & & 38 & & 88 & & \\
\hline
\end{tabular}

Berdasarkan tabel 9. dapat dilihat bahwa responden dengan pendidikan rendah yang unmet need IUD post-placenta sebanyak $66,7 \%$ dan yang met need IUD post-placenta adalah $33,3 \%$. Responden dengan pendidikan tinggi yang unmet need IUD Post-placenta sebanyak $51 \%$ dan yang met need IUD Post-placenta adalah $49 \%$. Hasil uji statistik dengan menggunakan Chi-square diperoleh nilai $p=0,222(p>0,05)$. Berdasarkan hasil tersebut, dapat disimpulkan bahwa tidak ada hubungan antara pendidikan dengan unmet need KB Pasca-salin IUD Post-placenta. Ini artinya tidak terdapat kecenderungan bahwa pendidikan tinggi akan berpengaruh pada pemakaian kontrasepsi IUD setelah melahirkan.

Pendidikan merupakan salah satu faktor yang dapat mempengaruhi persepsi seseorang untuk menerima ide-ide baru, termasuk untuk menggunakan alat kontrasepsi setelah melahirkan. Menurut Soekanto (2003), bahwa semakin tinggi tingkat pendidikan maka semakin mudah untuk menerima informasi, sehingga semakin banyak pula pengetahuannya. ${ }^{17}$ Penelitian ini tidak sejalan dengan penelitian yang dilakukan oleh Tatarini Purba yang menyatakan adanya hubungan antara pendidikan dengan pemakaian alat kontrasepsi $(p=0,03){ }^{18}$

Tabel 10. Hubungan status ekonomi dengan unmet need KB pasca-salin IUD post-placenta

\begin{tabular}{|c|c|c|c|c|c|c|c|}
\hline \multirow{3}{*}{$\begin{array}{l}\text { Status } \\
\text { ekonomi }\end{array}$} & \multicolumn{4}{|c|}{ Wanita PUS } & & & \multirow{3}{*}{$\begin{array}{c}p \\
\text { value }\end{array}$} \\
\hline & \multicolumn{2}{|c|}{$\begin{array}{l}\text { Unmet need } \\
\text { IUD Post- } \\
\text { placenta }\end{array}$} & \multicolumn{2}{|c|}{$\begin{array}{c}\text { Met } \\
\text { needlUD } \\
\text { post- } \\
\text { placenta }\end{array}$} & \multicolumn{2}{|c|}{ Total } & \\
\hline & $f$ & $\%$ & $f$ & $\%$ & $f$ & $\%$ & \\
\hline $\begin{array}{l}\text { Kurang } \\
\text { mampu }\end{array}$ & 36 & 56,2 & 28 & 43,8 & 64 & 100 & 1,000 \\
\hline Mampu & 14 & 58,3 & 10 & 41,7 & 24 & 100 & \\
\hline Total & 50 & & 38 & & 88 & & \\
\hline
\end{tabular}

Berdasarkan tabel 10. dapat dilihat bahwa dari 64 responden yang berstatus ekonomi kurang mampu, sebanyak $56,2 \%$ unmet need IUD Postplacenta dan $43,8 \%$ met needIUD post-placenta. Responden yang berstatus ekonomi mampu yang unmet need IUD post-placenta sebanyak 58,3\% dan yang met need IUD post-placenta sebanyak $41,7 \%$. Hasil uji statistik dengan menggunakan Chi-square diperoleh nilai $p=1,000$ ( $p>0,05)$. Berdasarkan hasil tersebut, dapat disimpulkan bahwa tidak ada hubungan antara status ekonomi dengan unmet need KB pasca-salin IUD Post-placenta.

Status ekonomi suatu keluarga juga dapat berpengaruh terhadap pemilihan kontrasepsi. Hal ini disebabkan karena untuk mendapatkan pelayanan kontrasepsi yang dibutuhkan, peserta harus menyediakan dana yang diperlukan. Analisa lanjut SDKI 2007 mendapatkan hasil bahwaada asosiasi yang signifikan antara tingkat ekonomi Rumah Tangga 
dengan penggunaan alat kontrasepsi dan memiliki tingkat korelasi positif. ${ }^{14}$ Menurut Manuaba (1998), faktor ekonomi termasuk ke dalam faktor-faktor yang mempengaruhi seseorang dalam pemilihan alat kontrasepsi selain pekerjaan dan layanan kontrasepsi yang terjangkau. Masalah ekonomi ini dapat dilihat dari adanya keterkaitan antara pendapatan dengan kemampuan membayar seorang individu. ${ }^{19}$

Tabel 11. Hubungan konseling $\mathrm{KB}$ dengan unmet need KB pasca-salin IUD post-placenta

\begin{tabular}{|c|c|c|c|c|c|c|c|}
\hline \multirow{3}{*}{$\begin{array}{c}\text { Konseling } \\
\text { KB }\end{array}$} & \multicolumn{4}{|c|}{ Wanita PUS } & \multirow{2}{*}{\multicolumn{2}{|c|}{ Total }} & \multirow{3}{*}{$\begin{array}{c}p \\
\text { value }\end{array}$} \\
\hline & \multicolumn{2}{|c|}{$\begin{array}{c}\text { Unmet } \\
\text { need IUD } \\
\text { Post- } \\
\text { placenta }\end{array}$} & \multicolumn{2}{|c|}{$\begin{array}{c}\text { Met } \\
\text { needIUD } \\
\text { post- } \\
\text { placenta }\end{array}$} & & & \\
\hline & $f$ & $\%$ & $f$ & $\%$ & $f$ & $\%$ & \\
\hline Kurang & 38 & 59,4 & 26 & 40,6 & 64 & 100 & \\
\hline Baik & 12 & 50 & 12 & 50 & 24 & 100 & \\
\hline Total & 50 & & 38 & & 88 & & \\
\hline
\end{tabular}

Berdasarkan tabel 11. dapat dilihat dari 64 responden yang mendapat konseling $\mathrm{KB}$ yang kurang baik, 59,4\% diantaranya unmet need IUD postplacenta dan $40,6 \%$ sisanya met needIUD postplacenta. Dalam kelompok responden yang mendapatkan Konseling KB yang baik, sebanyak $50 \%$ unmet need IUD post-placenta dan 50\% met need IUD post-placenta. Hasil uji statistik dengan menggunakan Chi-square diperoleh nilai $p=0,583 \quad(p>0,05)$. Berdasarkan hasil tersebut, dapat disimpulkan tidak ada hubungan antara konseling KB dengan unmet need KB pasca-salin IUD post-placenta. Hal ini dapat dilatarbelakangi oleh banyaknya sumber informasi yang dapat digunakan oleh lbu selain konseling KB untuk mengambil keputusan akan jenis alat kontrasepsi apa yang akan digunakannya. Sumber informasi itu dapat berupa media cetak, elektronik, pengalaman dari teman atau kerabat terdekat.

Konseling merupakan aspek yang penting dalam pelayanan Keluarga Berencana.Dengan melakukan konseling berarti petugas membantu klien dalam memilih dan memutuskan jenis kontrasepsi yang digunakan sesuai dengan pilihannya.Namun demikian, seringkali konseling diabaikan dan tidak dilaksanakan dengan baik karena petugas tidak mempunyai waktu dan tidak menyadari pentingnya konseling. Konseling KB dapat dilaksanakan di lapangan yang dilakukan oleh petugas KB di lapangan maupun di klinik yang dilakukan oleh petugas medis dan paramedis terlatih, seperti dokter, bidan, perawat, dan bidan desa. ${ }^{20}$

\section{KESIMPULAN}

Setelah dilakukan penelitian mengenai faktorfaktor yang berhubungan dengan unmet need KB pasca-salin IUD post-placenta, maka dapat disimpulkan :

a. Tidak dapat dinyatakan ada tidaknya hubungan antara dukungan keluarga dengan unmet need KB pasca-salin IUD post-placenta.

b. Ada hubungan yang bermakna antara tingkat pengetahuan lbu mengenai kontrasepsi dengan unmet need KB pasca-salin IUD postplacenta.

c. Tidak adanya hubungan yang bermakna antara pendidikan dengan unmet need KB pasca-salin IUD post-placenta. d. Tidak adanya hubungan yang bermakna antara status ekonomi dengan unmet need KB pascasalin IUD post-placenta.

e. Tidak adanya hubungan antara konseling KB dengan unmet need KB pasca-salin IUD postplacenta.

\section{DAFTAR PUSTAKA}

1. SDKI. Survei Demografi Kesehatan Indonesia. Jakarta: Depkes; 2007.

2. Bappenas. Laporan pencapaian millenium development goals 2007. 2007 (diunduh 17 April 2012). Tersedia dari http://p3b.bappenas.go.id/handbook /docs/14.\%20\%20MDG\%202007\%20 report\% 20BI.pdf

3. BKKBN. Pedoman pelayanan KB dalam jaminan kesehatan masyarakat. Jakarta : BKKBN; 2009.

4. USAID. The ACQUIRE project : The postpartum intrauterine device, a training course for service providers, participant Handbook. 2008 (diunduh 9 Juli 2012). Tersedia dari http://www.engenderhealth.org/files/pubs/acq uire-digital-

archive/10.0_training_curricula_and_material s/10.2_resources/ppiud_ph _ complete updated.pdf

5. Widyastuti L. Postpartum contraceptive use in indonesia: Recent patterns and determinants. 2010. (diunduh 17 April 2012). Tersedia dari http://itp-bkkbn.org/pulin/004population_data_information/ 004_Postpartum_Contraceptive-Lina.pdf).

6. Muthal-Rathore A. Immediate postpartum insertion for intrauterine devices". The WHO Reproductive Health Library; Geneva : World Health Organization". 2010 (diunduh 11 Juli 2012). Tersedia dari http://apps.who.int /rhl/fertility/contraception/cd003036_muthalrat horea com /en/index.html

7. Winarni E. Pemantauan pasangan usia Subur (PUS) Melalui Mini Survei di Indonesia 2008. Puslitbang BKKBN : Jakarta. 2010.

8. Ekoriano M, Maria A, Popy. Upaya meningkatkan pemakaian alat kontrasepsi (KB) pasca persalinan dan pasca keguguran di rumah sakit, (diunduh 18 April 2012). Tersedia dari http://www.bkkbn.go.id /litbang/pusna /Data/Policy\%20Brief \%20Upaya\%20KB\%20di\%20RS\%20_mario[1 ].pdf

9. Grimes, David A, et al. Immediate postpartum insertion of intrauterine devices. Cochrane Database of Systematic Reviews, Issue. 2010 (diunduh 18 April 2012). Tersedia dari www.who.int/rhl/reviews/CD003036.pdf

10. Edelman, David A., Alfredo G, James D.Shelton. Postpartum Contraception. International Journal of Gynaecology and Obstetrics. 1981. Volume 19 nomor 4: 305-11.

11. O'Hanley K, Douglas H. Huber. Postpartum IUDs : Keys for success. Contraception. 1992; 45 (4): 351-61, (diunduh 18 April 2012). Tersedia dari http://www.science direct.com /science/article/pii /001078249290057Z 
12. Sarwono, Jonathan, Budiono H. Aplikasi untuk riset skripsi, tesis, dan disertasi. Jakarta: Elex Media Komputindo; 2002.

13. Hartanto $H$. Keluarga berencana dan kontrasepsi. Jakarta: Pustaka Sinar Harapan; 1996.

14. BKKBN.Hasil analisa lanjut SDKI 2007. 2009. (diunduh 14 Maret 2013). Tersedia dari http://www.bkkbn.go.id /litbang/pusna/Hasil\%20Penelitian/ Analisis\%20Lanjut/Tahun\%202009/Penggun aan\%20alat\%20kontrasepsi\%20\%20pasca\% 20melahirkan.pdf

15. Notoatmodjo S. Kesehatan Masyarakat : IImu dan Seni. Jakarta: Rineka Cipta; 2007.

16. Destyowati M. Hubungan tingkat pengetahuan ibu tentang kontrasepsi IUD dengan minat pemakaian kontrasepsi IUD Di desa Harjobinangun kecamatan Grabak kabupaten Purworejo Tahun 2011. Jurnal Komunikasi Kesehatan. 2012; 3(2). (diunduh 14 Maret 2013) Tersedia dari http://ejournal.akbid-purworejo.ac.id

17. Soekanto. Sosiologi suatu pengantar. Jakarta: PT Raja Grasindo; 2003.

18. Tatarini $P$, Junita. Faktor - faktor yang mempengaruhi pemakaian alat kontrasepsi pada istri PUS di kecamatan Rambah Samo kabupaten Rokan Hulu tahun 2008 (tesis). Medan: Sekolah Pascasarjana Universitas Sumatera Utara; 2009.

19. Manuaba IBG. IImu kebidanan, penyakit kandungan dan keluarga berencana untuk Pendidikan Bidan. Jakarta: EGC; 1998.

20. Saifuddin, Abdul B. Buku panduan praktis pelayanan kontrasepsi. Edisi ke-2. Jakarta: Yayasan Bina Sarwono Prawirohardjo; 2006. 